\title{
University Councils: an institutional innovation in German universities
}

\section{RENATE MAYNTZ}

Article by an MPIfG researcher

Renate Mayntz: University Councils: An Institutional Innovation in German Universities. In: European Journal of Education:

Research, Development and Policies 37(1), 21-28 (2002). Wiley-Blackwell - SSH

The original publication is available at the publisher's web site: http://dx.doi.org/10.1111/1467-3435.00088

\section{Introduction}

In the German federal system, education policy is constitutionally assigned to the federal States, the Länder. A federal framework law (Hochschulrahmengesetz) regulates such matters as the legal status of universities (which are still overwhelmingly public institutions) and of the university personnel (university professors, for instance, are civil servants), but the details of university organisation and of teaching programmes are decided by the state ministries of education. ${ }^{1}$ These public authorities also have final responsibility for the recruitment of professors: they often follow, but may reject and change the list of candidates submitted by a university, and they also negotiate the financial conditions offered to a candidate. German public universities do not receive global budgets, but must operate within the confines of a cameralistic finance system; nor can they select their students. The public status and politically dependent position of German universities, which evidently restrict the scope for effective university-level steering, are the main reasons usually given for their apparent inability to reform and adapt to changing demands. In addition, their traditional internal structure, with self-governing departments, restricts the university leadership's powers of strategic planning and intervention in the operation of the departments. When the period of the German economic miracle ended and budgets had to be cut in the face of growing student numbers, this launched a heated debate about university reform. In this debate, international comparisons which showed that German universities functioned less efficiently than those in other Western societies played an important role. In the greater competitive spirit of our age, benchmarking exercises draw attention to deficits. But they also stress which systems work well and could serve as models. In Germany, this role has mainly been played by American universities. Of particular interest was their apparently very effective governance structure, characterised by powerful Boards of Trustees and powerful Deans.

In the last 20 years, there have been a number of attempts at university reform, both on the part of the government and of individual universities. Many have been watered down or have foundered in the cross-currents of conflicting demands for more autonomy on the part of the universities and for more effectiveness on the part of politics. More recently, the reform movement has finally gained impetus in Germany, which has lagged behind other countries such as Sweden or the Netherlands in granting universities greater freedom from strict bureaucratic 
control. The introduction of university councils (Universitätsräte, or Hochschulräte) with the amendment of existing state laws that regulate the institutions of higher learning (Hochschulgesetze) must be seen against this background.

Not all the federal States have yet introduced such councils. Some of the present Hochschulgesetze of federal States only provide for the introduction of an advisory board supposed to improve the relationship between the university and its social environment. Normally called Kuratorium, these boards are composed of representatives of the major sectors of society - industry, labour, the churches, the media, etc. They are common throughout the academic system; most of the publicly funded research institutes (e.g. Max-Planck-Institutes) have set them up in the course of attempts to show more responsiveness to the concerns and expectations of society; they are not meant to increase efficiency. This, in contrast, is the purpose of university councils. Where they have recently been introduced by law, there are still considerable differences in their functions, the major one being between an advisory role and decision-making functions. In Hesse, for instance, the university council introduced by the amended Hochschulgesetz of the year 2000 has been given only advisory functions, but they cover all important aspects of management and development. In Baden-Württemberg and Saarland, in contrast, the newly-instituted university councils have been given significant veto powers and strategic planning functions. Bavarian university councils are again mainly advisory, but do share in some strategic planning tasks. Where amendments of the Hochschulgeset $z$ are now being considered or in the process of legislation, university councils tend to have more than a merely advisory role.

The Hochschulgesetz in force at a given time does not necessarily preclude innovations. In Saxony, for instance, the university council, somewhat misleadingly called Kuratorium in the law of 1999, has only been given evaluative and advisory functions. Already in 1993, however, the Technical University of Dresden, used as an official test case for granting more financial autonomy to universities, set up a university council with significant decision-making powers in the field of finance. The University of Dresden receives a global budget from the State; the university council must approve the budget set up by the University, as well as most planned investment decisions. It also must evaluate and officially comment on the annual reports of the different faculties, which are also their teaching and research plans for the coming year.

University councils, particularly those with genuine decision-making powers, are an added link in the vertical hierarchy between the Ministry and university leadership. They are supposed to fulfil, or share in the task of fulfilling functions which formerly belonged either to the university leadership or to the Ministry. The rationale behind this institutional innovation has been spelt out by a reform commission of the Federal State of Lower Saxony. In the 'Ten Recommendations' formulated by this commission in 1997, the university council is designed as a supervisory board and likened to the Board of Trustees (Aufsichtsrat) of a corporation. ${ }^{2}$ Theoretically at least, the delegation of strategic planning functions from the university to the council means better control in the eyes of the Ministry; for the university, the delegation of supervisory functions from the Ministry to the council means more autonomy. Lower Saxony has, so far, only partly followed the recommendations of its own commission; the Hochschulgesetz of 1998 leaves it to the individual universities to decide whether they wish to introduce a university council, which, here too, is called Kuratorium 
and is attributed mainly advisory functions. But the new law being considered in the Lower Saxon Parliament goes far beyond this by granting universities more independence.

The council of the University of Konstanz, which is the empirical case on which much of the subsequent analysis is based, ${ }^{3}$ can be taken as an exemplary attempt to implement the Board of Trustees version of this new body. In $\$ 18$, the new Hochschulgesetz of Baden-Württemberg passed in February 2000 prescribes the formation of a university council composed of 13 members, 6 of whom are external members, i.e. they must come from outside the university in question. The university council 'carries responsibility for the development of the university', a function that is operationalised in a long list of tasks and powers. The statute of the University of Konstanz, which was adopted in September 1999, i.e. still under the previous Hochschulgesetz, anticipated the legal innovation. Based on an experimental clause added to the former Hochschulgesetz by an amendment of 1997, the new university statute stipulates the formation of a university council with genuine steering functions, composed only of external members. In view of the pending legislation, this statute received ministerial approval.

\section{The Structure of University Councils}

The members of a newly-formed university council are nominated by the university senate. At the University of Konstanz, a commission of the senate, in compliance with the provisions in $\$ 7$ of the university statute, selected the candidates for a council of seven external members; three of them had to be chosen jointly by the University and the Minister of Education. Following a vote by the senate, ${ }^{4}$ the Minister formally appointed the councillors. At their first meeting, the council members must elect a chairperson, but as is the rule in the case of newly-formed bodies, in Konstanz, a candidate for this position had previously been selected in informal talks with the university leadership. Also at the first meeting, the council agrees on rules of procedure. In Konstanz, a draft of these rules had been prepared by the university leadership in cooperation with some experienced future council members. It was accepted by the councillors with only minor modifications. According to these rules, the university council decides by simple majority; it must meet at least once during each semester, but has, in fact, met twice as often.

Both the university leadership and a representative of the minister participate in council meetings; they have a voice, but no vote. In Konstanz, the university leadership is made up of five persons: the Rector, the three vice-rectors who are responsible for teaching, research, and communication/information (e.g. library, data processing facilities, etc.), and the chancellor. They form the Rectorate and normally present a united front in council debates.

The relationship between the council and university leadership is fraught with possible tensions - and great opportunities. While in some universities the leadership apparently fails to sufficiently inform the council about current issues and tries to ward off its intervention in strategic decisions, in others it attempts to use the powers of the council to obtain support vis-à-vis departments that fail to respond to its expectations, and vis-à-vis the Minister of Education and his bureaucracy. Obviously, the kind of relationship it develops with the university 
council depends on the more reform-oriented or conservative attitude of a given university leadership (and particularly the Rector). In fact, the type of person proposed by the university leadership as external council member is sometimes an indicator of the future role it wishes the council to play.

The presence at council meetings of a state official from the section responsible for university matters reflects the linking function attributed to the council by the state government. Bureaucrats long used to wield their supervisory power and de facto steering functions are not necessarily happy if universities are to be granted more autonomy. The relationship between the university council and the Ministry is therefore also fraught with tensions, and all the more so when council and university leadership cooperate closely. In this case, it is the policy orientation of the responsible official that is important in shaping the role he plays in council meetings. In any case, the presence of an official from the state bureaucracy is of crucial importance for the effectiveness of council deliberations. The ministerial representative can give essential information for purposes of comparison with other state universities and about current policy and pending political decisions and he can comment directly on the feasibility of plans that need ministerial approval. Through the presence of its representative at council meetings, the minister obtains early information about university level developments and plans and timely warnings about emerging problems. Sometimes, a ministerial representative may support or even instigate council initiatives that promote a policy he deems to be in the interest of the universities but which meet with bureaucratic obstacles or intra-departmental opposition. Needless to say, similar exchanges of information, views, and requests also took place before the advent of university councils, but this happened in bilateral contacts, whereas now it takes place in the greater openness of an institutionalised forum. This may well serve to increase the substantive rationality of the deliberations in university/ministry interactions.

The kind of person who is chosen as councillor is of crucial importance for the functioning of the council and the way in which it makes use of its formal powers. As mentioned before, a basic decision is the composition of the council of both internal and external members, or of external members only, as is the case in Konstanz. ${ }^{5}$ Universities that have opted for a mixed composition in their statute may wish to avoid being exposed to a body that has no direct links with the institution it is to advise and even control. In selecting councillors from the university itself, one hopes that this will strengthen the identification of the council with the institution and induce it to use its powers in support of the university and its leadership. The consequences of a mixed composition are, however, not necessarily only positive. Internal council members can easily dominate in council deliberations because they are more informed. There is the danger that issues that have already been extensively discussed in the university senate are brought up again and lead to discussions in which the external members cannot fully join. Internal council members often seem to see themselves as representatives of a certain group, faculty, or discipline, and they may try to instrumentalise the council as a whole to serve these specific interests and to side with one of the parties in on-going intra-university conflicts.

A number of partly conflicting criteria are used in the selection of external council members: great public visibility, academic reputation, experience in science management, and a high, resource controlling position in some sectors

(C) Blackwell Publishers Ltd 2002 
such as industry or the media. It will obviously make a big difference for the policy stance of a councillor whether he used to be a university rector, manages a pharmaceutical firm, or is a well-known journalist. Great public visibility and a high position in non-academic fields are rarely combined with knowledge of and competence in university affairs or science management in general. Hence, external members often bring a very unorthodox perspective to council deliberations. Industrialists and bankers, for instance, think in terms of costefficiency and measurable returns for investment and tend to apply this perspective to the academic matters put before them. For them, it is difficult to understand the norms and bureaucratic procedures to which a public university is subject and which it must observe. They do not take a low ratio of students to professors, for instance, as an indicator of good learning conditions, but of low cost efficiency. Undoubtedly, the infusion of modern management practices into the university was an important goal behind the introduction of university councils; but the confrontation of very different perspectives, standards of evaluation, and fields of personal experience can lead to a clash of views, so that council deliberations are often laden with conflict among council members themselves. It does not make consensus building easier if the persons serving as councillors are used to give orders, be listened to and obeyed. If councillors take their office seriously, they will want to intervene actively in university affairs in order to shape the institution according to their own normative view of it. Academic experience is not necessarily a condition to exert influence, provided the university council disposes of sufficient powers. But there is, of course, the danger that interventions that are not solidly grounded in an understanding of the way universities operate are harmful rather than helpful. Well-meaning activism of this sort may irritate the more knowledgeable councillors and alienate the university leadership. In most cases, the composition of the council seems to ensure that a pragmatic approach is adopted after a heated debate. But the willingness to learn has its limits; if highly action-oriented persons get the feeling that, as councillors, they are unable to make decisions that really make a difference, that all they can do amounts to shadow-boxing, they will first object, and later become frustrated and not interested.

Lack of interest resulting from frustration is not the only reason for lagging attendance at council meetings. Leading industrialists and other influential people often cannot attend these meetings because of conflicting obligations. This introduces an element of discontinuity into council deliberations. On the other hand, they are able to use their position and the resources they control directly or indirectly for the benefit of the university. This may mean to sponsor, or mobilise sponsors for some university activities, an expensive laboratory instrument or even a new building, to donate a chair, or to engage in PR activities. Some highly influential persons are even able to address the Minister of Education directly, thus short-circuiting the official channels which a request must otherwise pass through.

\section{The Scope of University Council Action}

As a minimum, university councils are given an advisory function in all crucial matters of strategic planning - annual budgets, longer-term development plans and the distribution of resources to departments, chairs, and research centres. The 
statute of the University of Konstanz also attributes important veto powers to the university council. It must formally approve (1) the budget proposed by the University to the minister, (2) general principles formulated to guide the allocation of funds, (3) structure and development plans, (4) the establishment, change, and closure of central university institutions, and (5) the (re-)assignment of (vacant) chairs to given fields and the formal description of the expertise expected of candidates to a vacant professorship. Formally, veto powers such as these do not confer directive influence. Thus, the university council of Konstanz can, for instance, veto the proposed public announcement of a professorship submitted for its approval, and hence the filling of a vacancy at a given time and with a given orientation, but it cannot impose its definition of a different disciplinary orientation. In view of the limited substantive competence of external councillors and the specific interest orientation of internal councillors, this restriction of its strategic planning powers seems sensible. Formal veto powers, however, can motivate the ex ante adaptation to the anticipated reactions of the council, a wellknown mechanism that confers directive influence beyond formal power.

For a council which is both active and competent, it is possible to fully use a given formal power. This seems to have happened in Dresden, where the university council, which had had industrial managers among its external members, succeeded to introduce, in cooperation with the university leadership, modern financial controlling and accounting methods instead of the former cameralistic finance system, a feat that has been regarded as one of the six most outstanding reforms in German universities.

The scope of the de facto influence of the university council is greatly limited by several factors, even if councillors are highly motivated and dispose of significant formal powers. One of these is the lack of familiarity with academic matters. It requires highly specialised knowledge to give meaningful advice with respect to the introduction of new study programmes and degrees, a popular type of reform that aims to better adapt university teaching to the demands of the labour market. Obviously, external council members without relevant university experience will learn over time, but time is another limiting factor. For councillors who can, at best, devote a few days in the year to this office, even the assiduous study of annual reports and specially prepared statistical information will not suffice to provide the familiarity which is needed to anticipate correctly the preconditions of successful intervention and the possible negative consequences of a specific decision.

The greatest limit to the potential influence of the university council is the legal and budgetary constraints within which the university is able to move. If, for instance, as is the case in Baden-Württemberg, university budgets are frozen over several years, ${ }^{6}$ the council, which must approve the budget proposal prepared by the university, is de facto unable to propose any changes that would require additional funds. This seriously curtails its formal power with respect to decisions with financial implications. If, in addition, there is no time to discuss the budget in detail because the university must meet a given deadline, the university council can only formally ratify what is put before it, and councillors may feel degraded to serve as bestellte Abnicker (summoned yes-men). In theory, of course, even a budget with a fixed ceiling still permits to make changes by redistributive measures, for instance by changes in the allocation of positions to different departments. Such measures, however, do not only meet with fierce opposition 
from those who are negatively affected, but often also collide with legal norms, which generally tend to cement the status quo. These norms - civil service law, labour law, Hochschulgesetz and the university statute - and their defensive use by vested interests within the university are a fourth limiting factor for council initiatives. The legal and political-administrative restrictions of university autonomy translate into restrictions of the scope of action conceded to university councils. In the light of these restrictions, the far-reaching formal powers given to a university council may seem a mere expression of symbolic politics.

The placement of the university council between the state bureaucracy on the one hand and the university and its leadership on the other makes for a complex multi-level structure of planning and decision-making where all three are involved. This, for instance, is the case for structure and development planning, a task assigned by law in Baden-Württemberg to the university leadership. While, at the University of Konstanz, the senate is only held (by law and university statute) to comment on the plan that has been prepared by the university leadership in collaboration with the departments (Stellungnahme), the university council must approve it. In one of its early meetings, the council first commented on the guidelines prepared by the university leadership to structure the plans which the departments were asked to draft. Later, the council will be able to discuss at length the voluminous and very detailed departmental plans presented to it by the university leadership and make critical comments and recommend changes before it finally takes a vote on the revised version of the plan. The university council thus participates at various stages in the planning process; its recommendations are given weight by its right - or formal obligation - of final approval. In the end, the structure and development plan must be submitted to the Minister of Education who must approve it. Being responsible for the coordination of the plans submitted by the various state universities, the minister must make sure that the planned profiles of teaching and research fit together and jointly present a portfolio that does not contain gaps and undesirable duplication. The plan developed by a university and approved by its university council thus does not necessarily become binding for future action, but may be in part rejected.

\section{Conclusion}

By virtue of their make-up, university councils have uncertain identities. On the one hand, they are control organs that are expected to make university management more efficient, and on the other they are tokens of a greater autonomy of the university vis$\grave{a}$-vis the state bureaucracy. The tension between these two orientations is built into the institution. University councils fulfil their functions only if this tension is sustained, instead of being resolved in favour of only one of the two functions. To achieve this precarious balance, the university leadership and the state representative must make their respective contributions. The reform impact is likely to be highest when all three parties involved agree on the direction university reform should take. But the reform impact of university councils also varies according to the functions they are attributed and their composition. Under favourable conditions, university councils have influenced the strategic orientation of a university and helped to implement specific reforms, e.g. of the study programme.

The novel institution of university councils can thus help to use the existing scope for making university management more effective, but this scope itself is 


\section{European fournal of Education}

limited by a whole hierarchy of legal norms - federal, state, and university. In the short run, this framework restricts even the most competent and highly motivated university council acting in agreement with a reform-oriented university leadership. In the long run, positive experience with this innovation may reinforce the readiness to grant more autonomy to universities. This will happen at the level of the university as a corporate actor, which implies less independence of its constituent parts from central interventions, an implication viewed critically by academics who defend their academic freedom and their greater competence to judge the importance of their research. Even if, for better or for worse, the expectations that the introduction of university councils will increase university autonomy are not fulfilled, their introduction may have - unintended - positive effects. Thus the Rector's obligation to report regularly on the university to the council, together with requests for specific information the council makes, such as information on student numbers, admissions, graduates, drop-out rates, vacancies in the academic staff, and external research grants, greatly improve the up-to-date information base of universities. Even if the crucial reform decisions must be made at the political level, the introduction of university councils is both an indicator and a factor of university reform in Germany.

\section{NOTES}

1. The term Ministry, instead of the more usual department, is used here to avoid confusion with university departments. Education, science/research, and technology are often combined in one ministry; for the sake of simplicity, here, they are only referred to as Ministry of Education.

2. Wissenschaftlicher Beirat zur Begleitung des Modellvorhabens für eine Erprobung der globalen Steuerung von Hochschulhaushalten im Land Niedersachen: Zehn Empfehlungen zur Einführung von Hochschulräten. 1997

3. The author is a member of the university council of Konstanz University, which at the time of writing (August 2001) had just held its sixth meeting. Documentary material kindly supplied by the German Science Council and interviews with persons familiar with other university councils complement the data used for this article.

4. The university senate is the highest decision-making organ of the university, its legislature, so to speak; amongst its elected members there are representatives of all groups within the university - professors, assistants, students, and service personnel.

5. The composition of the council is very mixed and includes representatives from industry, the banking sector, the media, and science and research.

6. In Baden-Württemberg, an agreement between the state government and the universities, euphemistically called Solidarpakt, gives the state universities the assurance that their budget will remain stable for several years in exchange for agreed-upon cuts, last but not least among the generally stateallocated positions. 